\title{
Investigation of ecological environment and assessment of ecological security in Tieshan Reservoir watershed
}

\author{
Na Wang ${ }^{1}$, Ying Wang ${ }^{2, *}$, and Zhan Liu ${ }^{1}$ \\ ${ }^{1}$ Hunan Provincial Key Laboratory of Water Pollution Control Technology, Hunan Research \\ Academy of Environmental Sciences, Changsha, 410012, China \\ ${ }^{2}$ Institute of Environmental Information, Chinese Research Academy of Environmental Sciences, \\ Beijing, 100012, China
}

\begin{abstract}
In this study, based on the "Driver-Pressure-State-Impact-Response" (DPSIR) assessment model, an assessment index system aming at the Tieshan Reservoir watershed was established from 4 aspects including social-economic impact, ecological subsystem, ecological service subsystem, regulation and management. Eighteen major items containing 55 indexes were selected in the assessment index system. Furthermore, the ecological security index (ESI) was calculated, and the deviation degree of reservoir ecological safety from the standard state was assessed. Results showed that ecological security index of Tieshan Reservoir watershed is 89 , ecological security level is I, indicating security. The low security indexes of total phosphorus and total nitrogen were the major disadvantage factors that affected the ecological security of Tieshan Reservoir watershed, including rural life pollution and farmland runoff pollution. In addition, long-term mechanism of protection and development has not been formed yet, which also restricts the economic growth. Strengthening the formulation of laws and regulations on environmental protection, tamping the basic capacity building of water pollution control, developing ecological agriculture and green tourism are the important ways to improve the ecological security and realize the sustainable development of Tieshan Reservoir watershed.
\end{abstract}

Key words: DPSIR model, Ecological security, Evaluation index system, Assessment, Tieshan Reservoir watershed.

Ecological security refers to the state of the ecosystem that can maintain and guarantee the sustainable development of human society without damaging or threatening the health and integrity of the ecosystem itself, including natural ecological security, economic ecological security and social ecological security ${ }^{[1]}$. As an important part of aquatic ecosystem, lakes and reservoirs are important ecological resources in China. They have the functions of regulating runoff, providing water resources, flood control and irrigation, and maintaining biodiversity. Tieshan reservoir, located in Yueyang City, Hunan Province, is

\footnotetext{
*Corresponding author: 553853554@qq.com
} 
an important drinking water source in China. It is responsible for the water supply of more than 1 million people in Yueyang City and Yueyang County, as well as the farmland irrigation of 46 surrounding towns. It plays an important role in ensuring the safety of drinking water and the ecological security of the river basin. This study mainly evaluated the ecological security of Tieshan reservoir basin from four aspects ${ }^{[2]}$ : the impact of social and economic activities on reservoir water quality and water environment, the health of water ecosystem, the regulation of ecological service function and human "feedback" measures on social and economic development, and the improvement of reservoir water quality and water ecology. According to the "driving force-pressure-state-impact-response" (DPSIR) $^{[3 \sim 6]}$ evaluation model, the ecological security evaluation index system is constructed. By calculating the index weight and the value of each level [7], the comprehensive ecological security index (ESI) is obtained, so as to evaluate the ecological security status of Tieshan reservoir, and provide support for scientific management and decision-making of Tieshan reservoir watershed ecosystem.

\section{General situation}

Tieshan reservoir is located at Tieshankou, Gongtian Town, Yueyang County, Hunan Province. It is the core area of National Wetland Park of Xinqianghe in Hunan Province. The large reservoir was built in 1983 with a total storage capacity of 635 million cubic meters ${ }^{[8]}$, and the water surface area of 53.3 square kilometers. The basin covers a total area of 496 square kilometers, which governs Maotian Town, Yuetian Town, Gongtian Town and Pingjiang County, and Banjiang Township of Pingjiang County. There are seven main rivers in Tieshan reservoir basin, which are Yuetian River, Wujiaduan River, Maotian River, Yingqiao River, Xiaogang River, Dongqi River and Shagang River. The terrain of Tieshan reservoir basin is high in Northeast and low in northwest, with the terrain fluctuating and high, and the altitude is $49-952 \mathrm{~m}$. The average annual temperature in the basin is $17^{\circ} \mathrm{C}^{[9]}$, and the average annual rainfall is $1451 \mathrm{~mm}{ }^{[10]}$, and the annual precipitation is mainly concentrated from March to June.

\section{Research methods}

\subsection{DPSIR model}

DPSIR model was proposed by the European Environment Agency in 1997, which provides a more flexible system for the study of ecological security level ${ }^{[11]}$. In DPSIR model, the demand of population, society and economy development as driving force (D) brings about the increase or decrease of environmental pressure (P), and leads to the change of ecological environment state (S). When the ecological environment status changes, it will have a certain impact on the service function of the ecosystem (I), Thus, human society responds to the ecological crisis and improve the ecological destruction mode (R), as shown in Figure 1. 


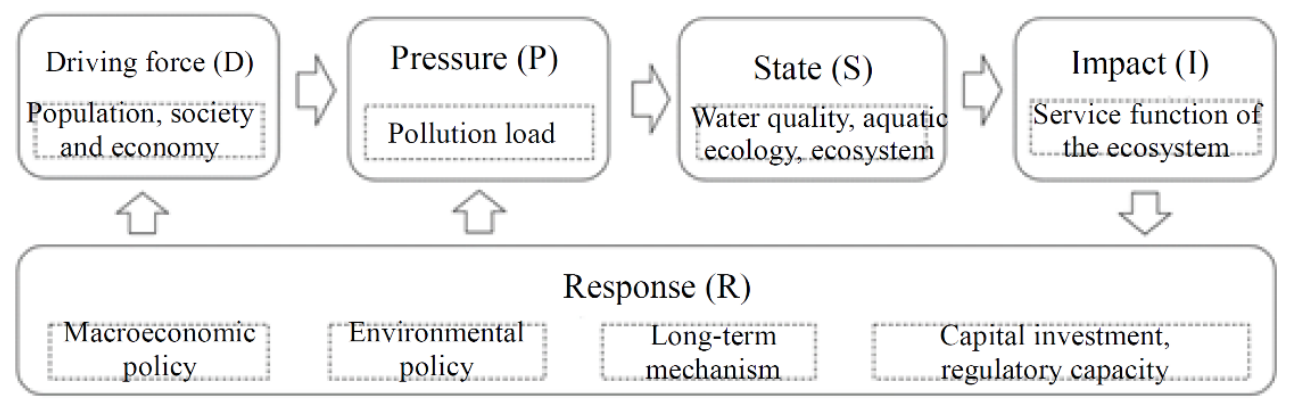

Fig. 1. Frame diagram of DPSIR model.

\subsection{Selection of evaluation index and construction of evaluation system}

In order to evaluate the ecological security of Tieshan reservoir basin objectively and scientifically, the evaluation indexes are selected according to the principles of systematicness, purposefulness, representativeness, scientificity, comparability and adaptation to local conditions. In this study, socio-economic impact index is used to represent the driving force (D) of the change of Tieshan reservoir ecological environment caused by human socio-economic activities; The pollution load caused by various kinds of pollution discharge is used as the pressure (P), and the ecological health index is used to describe the current situation of the ecosystem in Tieshan reservoir basin driven by pressure (S); The ecosystem function of Tieshan reservir watershed was described by the index of ecosystem service function (I); The regulation and management index is used to reflect the improvement effect of human feedback measures on social economy, water quality and biodiversity $(\mathrm{R})$.

The ecological security index system of Tieshan reservoir watershed is constructed according to four levels: target layer (layer V), scheme layer (layer A), factor layer (layer B) and index layer (layer C). The first layer is the target layer, which is the ecological security index of Tieshan reservoir basin, reflecting the overall situation of ecological security of Tieshan reservoir basin. The second layer is the scheme layer, which is used to establish the DPSIR framework. The driving force index, pressure index, state index, impact index and response index in the framework model are represented by human socio-economic activities, water ecological health, service function and water environment and water resources management regulation. The third layer is the factor layer, which classifies and proposes the factors that affect human social and economic activities, water ecological health, service function, water environment and water resources management and regulation. The fourth layer is the index layer, which is the specific index representation of the factor layer. According to the principle of index selection, 18 factors and 55 indexes are finally determined, as shown in Table 1.

Table 1. Indices system for ecological security assessment in the Tieshan reservoir watershed.

\begin{tabular}{|c|c|c|c|}
\hline $\begin{array}{c}\text { Target layer } \\
\text { (layer V) }\end{array}$ & $\begin{array}{c}\text { Scheme layer } \\
\text { (layer A) }\end{array}$ & $\begin{array}{l}\text { Factor layer (layer } \\
\text { B) }\end{array}$ & Index layer (layer C). \\
\hline $\begin{array}{l}\text { Comprehensive } \\
\text { index of } \\
\text { ecological } \\
\text { security }\end{array}$ & $\begin{array}{l}\text { Socio economic } \\
\text { impact (A1) }\end{array}$ & $\begin{array}{c}\text { Social } \\
\text { development (B1) } \\
\text { Economic growth } \\
\text { (B2) } \\
\text { Resource } \\
\text { constraints (B3) }\end{array}$ & $\begin{array}{c}\text { Population growth rate }(\mathrm{C} 11) \\
\text { Urbanization rate }(\mathrm{C} 12) \\
\text { Population density }(\mathrm{C} 13) \\
\text { GDP growth rate }(\mathrm{C} 21) \\
\text { GDP per capita (C22) } \\
\text { Cultivated land area per capita }(\mathrm{C} 31) \\
\text { Proportion of urban land }(\mathrm{C} 32)\end{array}$ \\
\hline
\end{tabular}




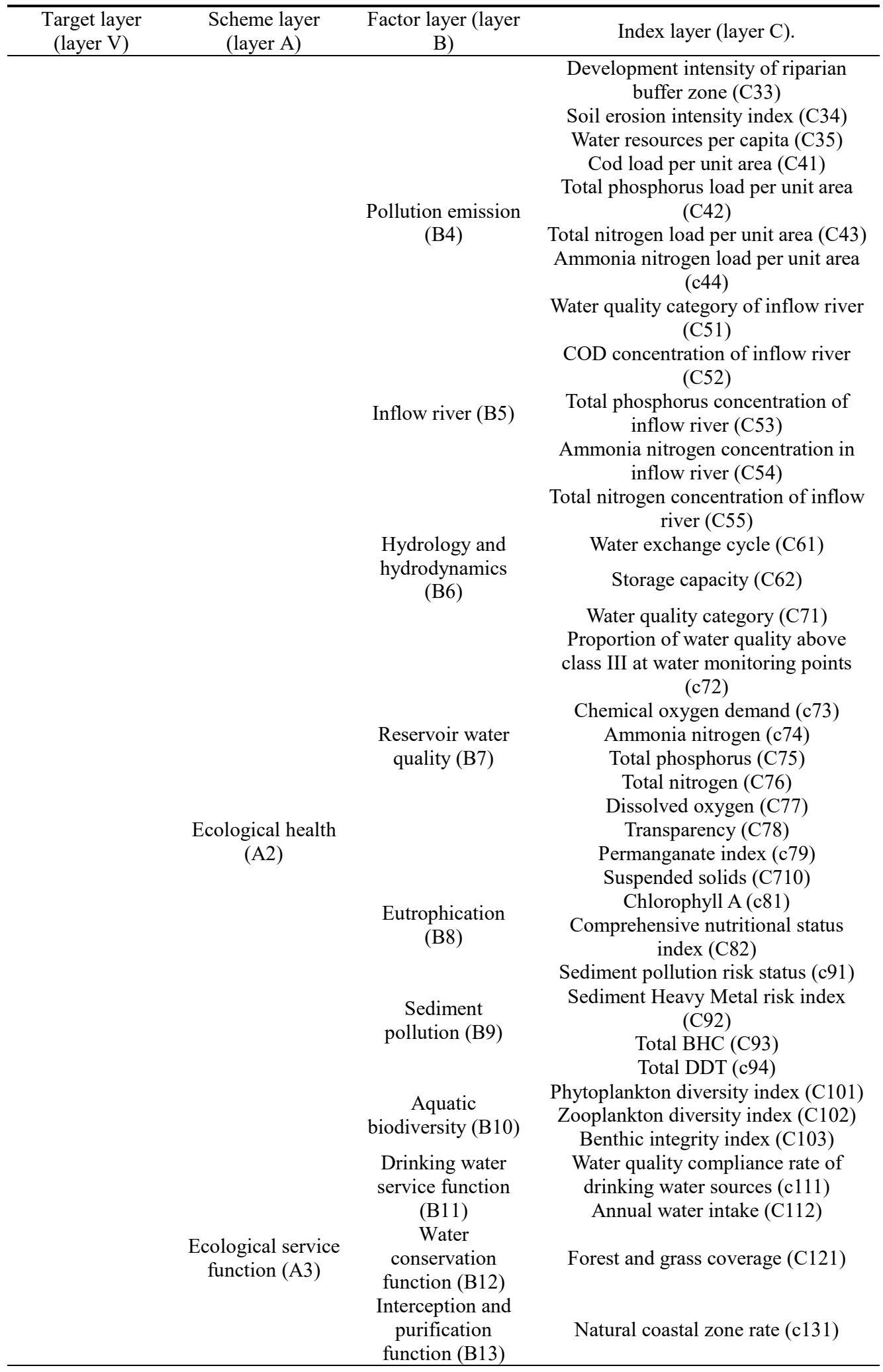




\begin{tabular}{|c|c|c|c|}
\hline $\begin{array}{l}\text { Target layer } \\
\text { (layer V) }\end{array}$ & $\begin{array}{c}\text { Scheme layer } \\
\text { (layer A) }\end{array}$ & $\begin{array}{c}\text { Factor layer (layer } \\
\text { B) }\end{array}$ & Index layer (layer C). \\
\hline & \multirow{12}{*}{$\begin{array}{l}\text { Regulation and } \\
\text { management (A4) }\end{array}$} & $\begin{array}{l}\text { Human landscape } \\
\text { function (B14) }\end{array}$ & Wetland Park level (C141) \\
\hline & & $\begin{array}{l}\text { Capital investment } \\
\text { (B15) }\end{array}$ & $\begin{array}{l}\text { Environmental protection input index } \\
\text { (C151) }\end{array}$ \\
\hline & & \multirow{7}{*}{$\begin{array}{l}\text { Pollution control } \\
\qquad(\mathrm{B} 16)\end{array}$} & $\begin{array}{c}\text { Standard rate of wastewater } \\
\text { stabilization in industrial enterprises } \\
(\mathrm{c} 161)\end{array}$ \\
\hline & & & $\begin{array}{c}\text { Centralized treatment rate of urban } \\
\text { domestic sewage }(\mathrm{c} 162)\end{array}$ \\
\hline & & & $\begin{array}{l}\text { Collection and treatment rate of } \\
\text { municipal solid waste }(\mathrm{c} 163)\end{array}$ \\
\hline & & & $\begin{array}{l}\text { Centralized treatment rate of rural } \\
\text { domestic sewage }(\mathrm{C} 164)\end{array}$ \\
\hline & & & $\begin{array}{l}\text { Collection and treatment rate of rural } \\
\text { domestic waste (c165) }\end{array}$ \\
\hline & & & Comprehensive utilization rate of \\
\hline & & & livestock manure in rural areas $(\mathrm{C} 166)$ \\
\hline & & Regulatory & Standardized construction of drinking \\
\hline & & capacity (B17) & Regulatory capacity index (C172) \\
\hline & & $\begin{array}{l}\text { Long term } \\
\text { mechanism (B18) }\end{array}$ & $\begin{array}{l}\text { Construction of long term } \\
\text { management mechanism (c181) }\end{array}$ \\
\hline
\end{tabular}

\subsection{Weight determination}

Expert scoring method ${ }^{[12]}$ and analytic hierarchy process ${ }^{[13]}$ were used to determine the weight of each index. By means of questionnaire survey, 13 experts who are familiar with the ecological environment of Tieshan reservoir (composed of provincial scientific research institutes, staff of municipal and county environmental protection departments) were invited to score the importance of each index at the scheme level, factor level and index level respectively, and 1-10 was used to indicate the importance of the index to the ecological security of Tieshan reservoir basin, The higher the score, the more important it is. Through the judgment matrix, the weight of each index is calculated, and the weight value of each index is obtained.

Among them, the index layer weight calculation method is as follows:

$$
\mathrm{W}(\mathrm{CA})_{\mathrm{i}}=\mathrm{W}_{\mathrm{i}} * \mathrm{~W}(\mathrm{BA})_{\mathrm{i}}
$$

where, $W(C A)_{i}$ is the weight of index factor of layer $C$ relative to scheme layer $A ; W_{i}$ is the weight of index factor $C$ relative to factor layer $B$; $W(B A)_{i}$ is the weight of factor layer $\mathrm{B}$ relative to scheme layer $\mathrm{A}$.

The calculation method of scheme level index value is:

$$
\mathrm{B}_{\mathrm{i}}=\sum_{\mathrm{j}}^{\mathrm{m}} \mathrm{W}(\mathrm{CA})_{\mathrm{i}} * \mathrm{x}_{\mathrm{ij}}
$$

where, $B_{i}$ is the calculation result of the $i$ scheme layer; $x_{i j}$ is the index value of the evaluation index.

\subsection{Comprehensive calculation and evaluation}

According to the comprehensive calculation results of the index system, the weighted sum method is used to calculate the ecological security index (ESI), which is used to evaluate the overall ecological security status of the basin.

$$
\mathrm{ESI}=\sum_{\mathrm{i}}^{\mathrm{n}} \mathrm{B}_{\mathrm{i}} * \mathrm{~W}_{i}
$$


where ESI is the ecological security index; $B_{i}$ is the value of the $i$ scheme layer; $W_{i}$ is the weight of the i scheme layer.

According to the guideline for ecological security assessment of reservoirs with excellent water quality (Trial), this study divides the ecological security measurement standards into five levels: safe, relatively safe, generally safe, under safe and very unsafe ${ }^{[14]}$. See Table 2 for details.

Table 2. Grading criteria for ecological security index.

\begin{tabular}{ccc}
\hline $\begin{array}{c}\text { Ecological safety } \\
\text { grading }\end{array}$ & Grading standard & Ecological security degree \\
\hline V & $0<\mathrm{ESI} \leq 20$ & Not safe \\
IV & $20<\mathrm{ESI} \leq 40$ & A little unsafe \\
III & $40<\mathrm{ESI} \leq 60$ & Generally safe \\
II & $60<\mathrm{ESI} \leq 80$ & Relatively safe \\
I & $80<\mathrm{ESI} \leq 100$ & Safe \\
\hline
\end{tabular}

\section{Results and recommendations}

\subsection{Index survey and analysis}

\subsubsection{Socio economic impact}

This study has conducted a comprehensive investigation on the socio-economic impact indicators of Tieshan reservoir basin from 2012 to 2016, and analyzed the potential causes of social development, economy and resource constraints, pollution load and water quality of the river in storage. The survey selected three indicators of population growth rate, urbanization rate and population density to evaluate the social development of Tieshan reservoir basin. The total population of Tieshan basin has been rising slowly from 2012 to 2016 , with the population growth rate decreasing year by year, urbanization rate and domestic production increasing year by year, and the proportion of tertiary industry output value increasing. In 2016, the per capita cultivated land area of Tieshan basin was 0.08 hectares, with the per capita water resource share reaching 3081 cubic meters, and the proportion of urban land was only $4.2 \%$. There are no large industrial enterprises in Tieshan reservoir basin, and there are no enterprises with large wastewater discharge. Industrial enterprises mainly include wood and bamboo processing, prefabricated components, stone processing and other manual processing or small workshop enterprises, which have relatively little impact on water quality of the reservoir. Cod, total phosphorus, total nitrogen, ammonia and nitrogen are mainly from rural domestic discharge, With the continuous improvement of pollution treatment capacity in 2012-2016, the storage volume of major pollutants in the basin has decreased year by year.

\subsubsection{Water ecological health}

The hydrologic power, water quality, sediment and water ecology were selected to evaluate the water ecological health of Tieshan basin. Hydrologic dynamics reflects the self purification capacity of the reservoir, and the indexes include the water exchange period and the storage capacity. According to the investigation of water resources, Tieshan reservoir has a water exchange period of 383 days, and the normal water storage capacity is 500 million cubic meters, accounting for $92.0 \%$ of the normal storage capacity. 14 
monitoring sections (point positions) were set up in Tieshan reservoir and the river in storage in this survey, and monthly water quality monitoring was carried out for one year. After analysis, the overall water quality of Tieshan reservoir is excellent, and the water quality is of class II, and it is in the state of moderate eutrophication; The overall water quality of the river in storage is superior, and the water quality category is class II; Cod and total phosphorus exceeded the standard in the monitoring point and the section of the river.

Sediment pollution includes sediment pollution risk status, sediment heavy metal risk index and other indicators. Four sampling points were set up in Tieshan reservoir to carry out sediment monitoring. According to the evaluation of soil environmental quality risk control standard for agricultural land (Trial) (GB15618-2018), the sediment pollution index of Tieshan reservoir area is 1.5, which belongs to slight pollution. According to the Toxicity Coefficient of various heavy metals proposed by Hakanson, the comprehensive risk index of heavy metals in the sediments of Tieshan reservoir is 62.5 , which belongs to grade I mild risk.

Aquatic ecological indicators include phytoplankton diversity index and zooplankton diversity index at community level. A total of 11 sampling sites were set up in Tieshan reservoir area to monitor the species and quantity of plankton. Shannon Wiener diversity index $\left(\mathrm{H}^{\prime}\right)$ According to the formula, Tieshan reservoir phytoplankton diversity index and zooplankton diversity index were all slightly polluted.

\subsubsection{Ecological service function}

Tieshan reservoir has the functions of water supply, irrigation, tourism and so on. The indicators of drinking water service function, water conservation function, interception and purification function and human landscape function are used to reflect the ecological function status of Tieshan reservoir. The water quality of Tieshan reservoir is up to the standard rate of $100 \%$, and the annual water supply is about 85 million tons. The coverage rate of forest and grass accounted for $63.5 \%$ of the total basin area. Through remote sensing image interpretation, the natural shoreline rate of Kubin is $91.8 \%$.

\subsubsection{Regulation and management}

The regulation and management mainly reflects the economic policy, departmental policy and environmental policy of the river basin, and the indicators of investment in ecological environment, pollution control, regulatory capacity and long-term mechanism are selected to evaluate. In 2015, Tieshan reservoir launched the ecological environment protection project and increased the investment in the basin ecological environment protection. From 2015 to 2016, the investment accounted for $7.9 \%$ of the GDP, and the pollution control rate increased year by year. In accordance with the principles of "protecting people's livelihood and water quality, paying equal attention to two guarantees" and "city-county co-construction", the comprehensive treatment measures of "six controls and one treatment" such as control of relocation, control of construction, control of logging, control of mining, control of engineering, control of maintenance and pollution control has been formulated in Yueyang County, which has strongly promoted the protection of water resources in Tieshan reservoir area.

\subsection{Comprehensive Evaluation}

Based on the detailed socio-economic survey of Tieshan reservoir basin, as well as the monitoring of water quality and aquatic organisms, the current value of each index was obtained. Referring to the relevant standards, using the percentage system to score the 
indicators. For example, the development intensity index value of reservoir waterfront fluctuation buffer zone, Tieshan reservior reservoir waterfront zone is less disturbed by human activities, the proportion of natural reservoir waterfront zone reaches $91.8 \%$, and the ecological security score is 90; According to the index value of COD concentration, the water quality standard of COD concentration class $\mathrm{I}$ is $15 \mathrm{mg} / \mathrm{L}$, the average COD concentration of Tieshan reservoir is $9.48 \mathrm{mg} / \mathrm{l}$, and the ecological security score is 100 ; According to the index value of forest and grass coverage, it is proposed in the construction index of ecological civilization pilot demonstration county that "the forest and grass coverage in hilly area should be higher than $50 \% "$, and the forest and grass coverage in Tieshan reservior basin is $63.5 \%$, and the ecological security score is 100 .

According to the formula $(1) \sim(2)$, the socio-economic impact index is 88.5 , the ecological health index is 83.8, the ecological service function index is 95.4 and the regulation and management index is 88.7 . Using formula (3), the weighted sum calculation shows that the overall ecological security comprehensive index of Tieshan reservior basin is 89 , the ecological security degree is grade I, and the ecological security degree is safe. See Table 3 for Tieshan reservoir ecological security assessment index and classification results.

Table 3. Results of ecological security assessment.

\begin{tabular}{ccc}
\hline Scheme layer & Index value & Ecological security degree \\
\hline Socio economic impact & 88.5 & Safety \\
Ecological health & 83.8 & Safety \\
Ecological service & Safety \\
function & 95.4 & \\
$\begin{array}{c}\text { Regulation and } \\
\text { management }\end{array}$ & 88.7 & Safety \\
\hline
\end{tabular}

\subsection{Ecological security status of Tieshan Reservoir Basin}

The index of Tieshan reservoir ecological security assessment scheme layer has reached the security level, and the order from low to high is: ecological health index $<$ socio-economic impact index $<$ regulation and management index $<$ ecological service function index, which indicates that the ecological service function of Tieshan reservoir basin is excellent, the regulation and management measures are effective, and the social economy has a certain impact on the ecological security of the reservoir, There is still room for improvement in ecological health. Among the ecological health indicators, the safety index of total nitrogen in reservoir water quality and heavy metal risk index in sediment is low, while the safety index of population and economic growth index in socio-economic impact indicators and the safety index of total phosphorus and total nitrogen in inflow rivers is low. It can also be seen that:

(1) Rural domestic pollution is the main source of Tieshan reservoir water pollution, and the environmental awareness of rural residents needs to be strengthened. The COD, ammonia nitrogen and total nitrogen of Tieshan reservoir mainly come from rural domestic emissions; Total phosphorus mainly comes from rural life and scattered livestock breeding. Although the centralized treatment facilities for rural domestic sewage and domestic waste have been established in the reservoir area, due to the weak awareness of environmental protection of farmers, it is common to discard garbage and discharge sewage at will in daily life, which pollutes the water body of the reservoir.

(2) Farmland runoff pollution is becoming more and more serious, so it is imperative to actively guide farmers to develop ecological agriculture. The main source of agricultural non-point source pollution is the organic pollution caused by the use of agricultural fertilizers and pesticides. The unreasonable application of chemical fertilizer leads to a 
large number of nitrogen and phosphorus nutrients entering the reservoir with farmland drainage or rainwater, resulting in eutrophication of water body.

(3) The contradiction between protection and development is still prominent, and it is urgent to establish a long-term mechanism of protection and development from the policy level. The implementation of "six controls and one governance" measures in Yueyang County has played a significant role in improving and protecting the water quality of Tieshan reservoir. However, it can not be ignored that these control measures sacrifice a lot of economic development opportunities, and the economic income of the people in the reservoir area has been affected to a certain extent. As the development gap between the people in the reservoir area and the people outside the basin is widening, Their desire to keep pace with the times is growing.

\subsection{Suggestion}

It is suggested to strengthen the construction of ecological security in Tieshan reservoir basin from the following aspects: 1. Improve the system of ecological environment protection in the basin, and introduce a series of regulations such as Tieshan reservoir ecological environment protection regulations, reservoir ecological environment protection management measures, basin ecological compensation system, and reservoir ecological environment protection performance appraisal system. (2) Strengthen the basic capacity construction of water pollution prevention and control. We will further improve the construction of domestic pollution treatment projects, increase the coverage of supporting pipe networks of sewage treatment plants, and improve the construction of urban and rural domestic waste collection, transfer, and treatment and disposal systems. (3) Develop organic agriculture and reduce the environmental pollution and energy consumption caused by the extensive use of pesticides and chemical fertilizers. Develop ecological agriculture, apply organic fertilizer and legume rotation, use biological control technology and comprehensive control technology to control crop diseases and pests, and reduce the use of chemical pesticides. (4) Advocate green eco-tourism, rationally develop tourism resources, and promote the coordination of economic development and ecological protection. (5) Carry out environmental publicity and education, mobilize the enthusiasm and initiative of farmers to participate in environmental protection.

\section{Conclusion}

(1) The indexes of socio-economic impact, ecological health, ecological service function and regulation and management in Tieshan reservoir scheme layer are 88.5, 83.8, 95.4 and 88.7 respectively. The comprehensive ecological security index of Tieshan reservoir basin is 89 , and the degree of ecological security is grade I.

(2) The low safety index of total phosphorus and nitrogen in the inflow river and reservoir is the main factor affecting the ecological security of Tieshan reservoir basin.

(3) The water pollution of Tieshan reservoir mainly comes from rural life pollution and farmland runoff pollution; At the same time, the long-term mechanism of green development has not yet been formed, and the system of environmental protection system needs to be improved.

(4) In order to ensure the sustainable and healthy development of Tieshan reservoir basin, we should strengthen the formulation of laws and regulations on environmental protection, strengthen the construction of basic capacity for water pollution prevention and control, develop ecological agriculture and green tourism. 


\section{References}

1. LIU X F, SHAO Y Y, CUI S H, et al. Ecological security assessment in dongjiang lake watershed based on PSFR model[J]. Resources and Environment in the Yangtze Basin, 2015, 24(Z1): 197-205.

2. ZHANG L. Study on ecological security assessment of Hongze Lake[D]. Nanjing:Nanjing Forestry University, 2015.

3. JIAO J, LIU J. Comprehensive assessment of ecological security for Bosten Lake in Xinjiang[J]. Environmental Protection of Xinjiang, 2018, 40(3): 01-06.

4. WU H O, ZHANG Y P, TU X J, et al. Ecological security evaluation of reservoirs using DPSIR model in Zengcheng district, Guangzhou[J]. Pearl River, 2019, 40(4): 3744.

5. LI X Z. Research on land ecological security evaluation of Daqing City[D]. Harbin: Northeast Agricultural University, 2019.

6. ZHANG K, LIN N F, XU D L, et al. Research advance on ecological security in China: assessment models and management measures[J]. Journal of Ecology and Rural Environment, 2018, 34(12): 1057-1063.

7. LIU B. Investigation and evaluation of ecological security of Yunmeng Lake[D]. Jinan:Shandong University, 2017.

8. CAI J W, HU G H, GU Q F. Changing characteristics of precipitation in Tieshan Reservoir basin of Hu'nan Province[J]. Bulletin of Soil and Water Conservation, 2018, 38(3): 324-327(344).

9. CAI J W. Simulation of non-point source pollution in the Drinking Water basin of Tieshan Reservoir[D]. Changsha: Changsha University of Science \& Technology, 2018.

10. TANG Z, WANG Q, SHEN Y L, et al. Evaluation of water resources in drinking water source area of Tieshan Reservoir of lake-reservoir Type[J]. Yangtze River, 2017, 48(S2): 104-107(192).

11. CUI X Y, FANG L, WANG X R, et al. Urban eco-security assessment in the urban agglomerations based on DPSIR model: acase study of Yangtze River Delta, China. Acta Ecologica Sinica, 2021, 41(1) : 302-319.

12. XING G J, ZHAO M W. Assessing the ecological health of Qianhe Lake using grey correlation analysis method[J]. Journal of Irrigation and Drainage, 2019, 38(3): 121-128.

13. CAO B S, ZOU C X, GAO J X, et al. Review on methodology and application of ecological security assessment[J]. Journal of Ecology and Rural Environment, 2019, 35(8): $953-963$.

14. QUAN H B. Safety survey and appraisal research on ecology of Liujiaxia Reservoirs[D]. Lanzhou: Lanzhou University, 2019. 